\title{
Social and environmental reporting, sustainable development and institutional voids: Evidence from a developing country
}

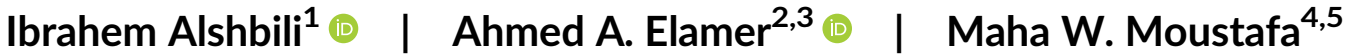

\author{
${ }^{1}$ Libyan Audit Bureau, Tripoli, Libya \\ ${ }^{2}$ Brunel Business School, Brunel University \\ London, London, UK \\ ${ }^{3}$ Department of Accounting, Faculty of \\ Commerce, Mansoura University, Mansoura, \\ Egypt \\ ${ }^{4}$ School of Computing, Electronics and Maths, \\ Coventry University, Coventry, UK \\ ${ }^{5}$ Department of Applied Statistics \& Insurance, \\ Mansoura University, Mansoura, Egypt

\section{Correspondence} \\ Ahmed A. Elamer, Brunel Business School, \\ Brunel University London, Kingston Lane, \\ London UB8 3PH, UK. \\ Email: ahmed.elamer@brunel.ac.uk; ahmed.a. \\ elamer@gmail.com
}

\begin{abstract}
This study adopts the concept of institutional voids to examine the perceptions of managers and policymakers in developing markets with respect to the actual barriers that hinder social and environmental reporting (SER) towards sustainable development. The study uses in-depth semi-structured interviews with managers and decision-makers and policymakers of the main oil and gas companies in weak institutional settings (Libya). The findings suggest that the absence of environment general authority's role, the absence of a clear legal requirement that refers to SER, the shortage of knowledge and awareness, the lack of motivation from the government, fear of change, and the absence of civil society organisations are perceived as the major barriers that hinder the development of SER. These findings contribute to the literature on institutional voids and sustainable development by providing evidence on SER barriers in the context of a developing country. Therefore, it could be useful to corporate regulators and policymakers to mitigate institutional voids to develop a more focussed SER agenda, when considering regulations for the disclosure and sustainable development.
\end{abstract}

\section{KEYWORDS}

developing countries, environmental policy, institutional voids, oil and gas industry, reporting barriers, social and environmental reporting, sustainable development

\section{1 | INTRODUCTION}

Over the last two decades, there have been substantial changes in government and social expectations about the goals that firms should determine (Adhikariparajul et al., 2019; Alnabsha et al., 2018; Alshbili et al., 2019; Gerged et al., 2018, 2020). This influences criteria that should be employed and reported to ascertain strong and weak corporate performance (Abdou et al., 2020; Elmagrhi et al., 2018; Fontana, 2020; Haque \& Ntim, 2018). Thus, social and environmental reporting (SER) has grown substantially (Bux et al., 2020; Farrukh et al., 2020; García-Rodríguez et al., 2013; García-Sánchez et al., 2020; Hoque et al., 2018; Javed et al., 2020; Kowalczyk \& Kucharska, 2020; Sharma, 2019). It has been widely accepted that SER is critical for firms' long-term survival. This is supported by an increasing body of evidence that demonstrates that SER has a positive influence on the economic performance of businesses (Tiba et al., 2019; Wahba, 2008; Waheed \& Yang, 2019; Wu, 2014; Zaid et al., 2020; Zou et al., 2019). Nowadays, numerous companies are diligently revising the notion of their environmental, social and sustainability responsibilities, since the influence of business in society is significant, in addition to the influence of business on economic growth and the sustainable development of country (Anser et al., 2018; Poddar et al., 2019; Pucheta-Martínez \& GallegoÁlvarez, 2019; Taylor et al., 2018). Therefore, SER defined as "the process of communicating the social and environmental effects of organisations' economic actions to particular interest groups within society and to society at large" (Gray et al., 1987, p. ix), has become a topical area of

This is an open access article under the terms of the Creative Commons Attribution-NonCommercial License, which permits use, distribution and reproduction in any medium, provided the original work is properly cited and is not used for commercial purposes.

(c) 2020 The Authors. Corporate Social Responsibility and Environmental Management published by ERP Environment and John Wiley \& Sons, Ltd. 
dialogue, and has brought an important growth of academic and business practitioners' interest in this field (Gerged et al., 2018).

Interestingly, however, previous research has revealed that in developing countries context, the level of SER is found to be generally low and unsatisfactory (Ali et al., 2017; Ali \& Frynas, 2018; Dobers \& Halme, 2009). For example, the extent of SER was found to be very poor in Yemen (Hussein, 2012), Bangladesh (Belal et al., 2010), a little in India (Poddar et al., 2019), very low in Egypt (Waheed \& Yang, 2019), low in Libya (Alshbili \& Elamer, 2019). Also, SER is small in the majority of the main oil and gas producers in Arab countries, such Saudi Arabia, Kuwait, Qatar, Oman, Bahrain, Jordan, and United Arab Emirates (Al-Abdin et al., 2018; Gerged, 2020). Such weakness in the level of SER towards sustainable development in developing countries suggests that contextual barriers may influence SER practises. For example, a strand of literature (Li et al., 2019; Martínez-Ferrero et al., 2019; Miniaoui et al., 2019; Pureza \& Lee, 2020) highlighted that legal system, standards and institutions, that support SER in Western countries are comparatively fragile. Likewise, Dobers and Halme (2009) and Jamali (2007) suggest that in developing countries contexts, the institutions, economic development, standards and official systems that encourage SER and its disclosure seem to be fairly weak. Increase our understanding of SER will thus involve both critical engagements with the main west-centric conceptualisations of SER and consideration of the distinct characteristics of and effects on the SER agenda in less developing countries. This paper contributes to the current literature by focusing on SER in the oil and gas sector in Libya because the oil and gas industry has been rarely studied in the past. Moreover, the Libyan oil and gas sector is interesting because it is accountable for substantial social, environmental and sustainable impact (Alshbili \& Elamer, 2019), but simultaneously it generates a significant contribution to the local and national economy (Alshbili \& Elamer, 2019). Furthermore, there are growing evidence that oil and gas companies face more industrial accidents, pollution, dangerous workplace conditions and humanitarian and ecological problems (García-Rodríguez et al., 2013; Lauwo et al., 2019).

Whilst there are a number of empirical studies (Ahmad \& Ishwerf, 2014; AlHares et al., 2020; Belal \& Cooper, 2011; Bufarwa et al., 2020; Feng et al., 2020; Hossain et al., 2016) that have attempted to identify the barriers to SER pursued by diverse stakeholders across different countries and by varying regulatory and governance systems, such studies results may not be generalisable, and thus may only remain applicable to the these countries' context. This is because particular barriers shape SER practise in every country (Kolk, 2005). Consequently, a question arises as to what are the barriers that may exist, which hinder companies from engaging largely in external disclosure within a developing country context. As such, this research aims to examine the perceptions of managers and policymakers in a developing country with respect to the actual barriers that act as major impediments to SER towards sustainable development. Specifically, previous research has highlighted developing context institutional voids and the challenges and opportunities they produce for these companies (e.g., Hill \& Mudambi, 2010; Marano et al., 2017). Institutional voids refer to "the absence or underdevelopment of institutions that enable effective markets, such as governance mechanisms that prevent corruption, protect property rights, ensure the rule of law, and establish supportive public investments and infrastructure" (Marano et al., 2017, p. 387). In particular, institutional voids obstruct the growth and flow of information and other resources and coerce economic opportunity by making social, environmental, regulatory and political uncertainty (Marano et al., 2017). Due to institutional voids, firms in less developing countries may employ SER towards sustainable development strategies to access more well-organised and munificent developed markets (Luo \& Tung, 2007; Marano et al., 2017).

Libya provides a mainly remarkable and valuable environment to study SER for a variety of reasons. Libya has seen dramatic changes in its government system, unlike developed markets, which are characterised by relative firmness in its systems of governance (Alnabsha et al., 2018; Eljayash, 2015). Thus, the state and its institutional context remain largely weak, with a number of local and non-state actors propelling the political change (Boduszyński \& Pickard, 2013). Furthermore, Libya's importance in terms of oil and gas production is unquestioned. Libya is a member of the organisation of petroleum exporting countries with the biggest oil reserves in Africa, which present about 3\% of the world's oil reserves, and thus, is a vibrant supplier to the worldwide supply of sweet and light crude oil (Alshbili \& Elamer, 2019). Therefore, firms that work in this sector are highly risky in terms of employee health and safety conditions and environmental repercussions (Alshbili \& Elamer, 2019). Taking into account the important role of the oil and gas industry in the Libyan economy and its distinctive characteristics, the environmental and sustainability developments of the industry is likely to become one of the pillars of environmental development, social wellbeing and economic growth of the country. Lastly, whilst previous literature on SER in Africa has focused largely on Nigeria and South Africa, a closer look shows that Libya is much less well researched. We, therefore, examine whether the decisions and behaviours of Libyan oil and gas firms confirm our current theory base or whether Libya's institutional void results in a different model of behaviour.

In so doing, our study contributes to the SER and sustainable development literature by first adding to the emerging empirical research body of SER studies which adopts a developing country perspective (Ahmad \& Ishwerf, 2014; Belal \& Cooper, 2011; Hossain et al., 2016; Martin \& Hadley, 2008). Second, by using the concept of the institutional void, ${ }^{1}$ this paper adds to the institutional voids literature towards understanding how different contextual barriers (e.g., the absence of Environment General Authority's [EGA's] role) act as major impediments to SER towards sustainable development in a fragile state. Finally, this research sheds light on the question of why firms in developing countries usually reveal very low of SER information (Ahmad \& Ishwerf, 2014; Beddewela \& Herzig, 2013; Belal \& Cooper, 2011; Hossain et al., 2016).

The paper proceeds as follows: in addition to this introductory section, Section 2 provides the background for the research by outlining the Libyan context and offers an overview of definitions of and barriers to SER practise. Section 3 highlights the data collection method and the data analysis technique. After that, the empirical results obtained from the analysed data are reported in Section 4. The research conclusion is presented in Section 5. 
TABLE 1 The legal and regulatory framework in Libya

\begin{tabular}{|c|c|}
\hline $\begin{array}{l}\text { Name of the law and/or } \\
\text { institution }\end{array}$ & Key aspects of the law \\
\hline $\begin{array}{l}\text { The Libyan commercial activity } \\
\text { law no } 23 \text { of } 2010\end{array}$ & $\begin{array}{l}\text { - The number of board members } \\
\text { has not been specified. } \\
\text { meard members are required to } \\
\text { - The general assembly assesses } \\
\text { the firm responses to the public } \\
\text { control office comments on the } \\
\text { annual reports. } \\
\text { - State-owned companies or joint } \\
\text { venture firms are required to } \\
\text { possess the subsequent } \\
\text { records: "a minute record of the } \\
\text { meetings of the board directors } \\
\text { and its decisions, a minute } \\
\text { record of the monitoring } \\
\text { committee's meetings and its } \\
\text { decisions, a minute record of } \\
\text { the meetings of the executive } \\
\text { committee and its decisions." }\end{array}$ \\
\hline
\end{tabular}

The Libyan Corporate

Governance Code 2005

The Stock Market Law 2010
- Part one-the essence of corporate governance and its significance in reducing the conflict of interest between parties.

- Part two-the criteria of the board, how they should perform their duties regarding the rights of shareholders, access to information, the attendance of the general meeting, voting rights.

- Part three-the choice of management and its supervisory role including an explanation of the most important tasks of the board of directors and how they should interact with the executive management.

- Part four-planning and policy formulations including a description of the responsibilities of the board of directors and the formulations and monitoring of policies and plans.

- Part five-auditing and internal control. All companies must develop procedures and policies of disclosure and supervisory regulations in written forms consistent with the LCGC rules.

- Covers elements such as: Control and management of the stock market, listing requirements, issuance rules, disclosure rules, exception from taxes and duties, establishing investment funds, authentic electronic documents in proof,
Relevant to firms working in the oil industry

Yes

It is voluntary but companies are asked to "comply-or-explain" basis.

LCGC indicates clearly that the disclosure and transparency elements are one of the most significant elements that have to be set in line with international accounting standards and to be revised consistent with the international auditing standards, but it did not clearly refer to SER.

\section{Require SER (yes/no)}

No clear articles referring to SER are clearly stated.
No as oil and gas firms are not No clear articles referring to SER listed on the LSML


TABLE 1 (Continued)

\begin{tabular}{|c|c|c|c|}
\hline \multirow[t]{2}{*}{$\begin{array}{l}\text { Name of the law and/or } \\
\text { institution }\end{array}$} & Key aspects of the law & $\begin{array}{l}\text { Relevant to firms working } \\
\text { in the oil industry }\end{array}$ & Require SER (yes/no) \\
\hline & $\begin{array}{l}\text { electronic signature, } \\
\text { organisation of resolution and } \\
\text { resolution board amongst } \\
\text { others. }\end{array}$ & & \\
\hline The Petroleum Law 1955 & $\begin{array}{l}\text { Petroleum is the property of } \\
\text { the Libyan state. } \\
\text { - Firms should prepare their } \\
\text { annual reports in accordance } \\
\text { with international accounting } \\
\text { standards and to be revised in } \\
\text { line with the international } \\
\text { auditing standards. }\end{array}$ & Yes & $\begin{array}{l}\text { No clear articles referring to SER } \\
\text { are clearly stated. }\end{array}$ \\
\hline $\begin{array}{l}\text { The Libyan accountants and } \\
\text { auditors association law no } \\
116 \text { of } 1973\end{array}$ & $\begin{array}{l}\text { - Issuing and monitoring } \\
\text { accounting standards in Libya. }\end{array}$ & Not active & $\begin{array}{l}\text { No clear articles referring to SER } \\
\text { are stated. }\end{array}$ \\
\hline $\begin{array}{r}\text { The Libyan general environment } \\
\text { authority law no. (15) of } 2003\end{array}$ & $\begin{array}{l}\text { - Concerned with environmental } \\
\text { issues in terms of regulation, } \\
\text { maintenance conservation of } \\
\text { natural resources; } \\
\text { environmental pollution control; } \\
\text { achieving sustainability } \\
\text { development; and integrated } \\
\text { planning of the community. }\end{array}$ & Yes & $\begin{array}{l}\text { No clear articles referring to SER } \\
\text { are clearly stated. }\end{array}$ \\
\hline
\end{tabular}

\section{2 | LITERATURE REVIEW AND THEORETICAL BACKGROUND}

\section{$2.1 \quad$ SER and its barriers}

Recent and on-going changes in Libya continue to focus on academic, practise and policy attention on the SER debate. On the institutional level, in a similar manner to other developing countries, in order to regulate the business environment, the state of Libya has issued several laws which expected to have a major impact on accounting practise, including SER, and has created a few institutions. The laws or constitutional regulations (legal systems) of a country can indirectly or directly influence its corporate reporting and disclosures practise (Alshbili \& Elamer, 2019). Table 1, therefore, outlines these laws, the key aspects of them, followed by whether it refers to SER or not. However, it seems that although the political and institutional changes have occurred in the country, significant shortcomings in the regulatory framework and legal system and the lack of environmental remediation facilities remain key issues.

Whilst the postwar government has already undertaken some steps towards sustainable development reforms, such as opening some opportunities for the private sector, increasing the level of foreign firms participating in the capital market (Chivvis \& Martini, 2014), economic policies did not change significantly, and thus, no sustainable development plans have been implemented yet (Khan \& Mezran, 2013). This is because the state was focusing exclusively on political and security developments (Khan \& Mezran, 2013).
Consequently, there are marked differences between the cultural and institutional context of Libya as compared with other countries, consist of a fragile state.

Indeed whilst a handful of studies have started to probe the barriers behind SER, the review of the literature shows that every country has its own barriers for not engaging in SER practise (Kolk, 2005). For example, empirically, using the questionnaire method, De Villiers (2003) examined the reasons behind nondisclosure of environmental information made by firms listed on the Johannesburg Stock Exchange in South Africa. The key barriers identified include: an absence of legal requirements, no demand for such information, SER is not applicable to this particular sector, no motivation to disclose such information, and the costs of disclosure exceeds the benefits of it. Although these findings have broad implications for corporate managers, such results may not be generalisable, and thus may only remain applicable to the South African context. Thompson and Zakaria (2004) find that a low level of SER in Malaysia is attributed to the lack of government and public pressures and the lack of perceived benefits from such practises. In contrast, Adams (2004) claim that cultural attitude within a country was a significant factor for low SER in Australia, whilst Gao et al. (2005) explained that the low of SER in Hong Kong owed to weak external pressures that Hong Kong companies have traditionally faced. In a similar vein, Lagasio and Cucari (2019) and Wu (2014) show that environmental problems, human rights abuses and other social biases remain dominant in the Tanzanian mining sector and that social, humanitarian and environmental 
problems seem to be implanted in and strengthened by the institutional structure of mining.

Furthermore, Belal and Cooper (2011) examined the barriers behind the absence of SER reporting in Bangladesh. Using 23 semistructured interviews with senior companies' managers, results imply that the key barriers for companies not to disclose information are: the absence of resources, absence of legal requirements, the profit imperative, absence of awareness and knowledge, performing poorly in terms of SER reporting, and fear of bad publicity. Additionally, although these results are consistent with the aim of the research, the authors were unsuccessful in examining perceptions of managers who deemed to be very important stakeholders, since they are in a position to have input on the formulation of both company reports and annual reports.

Within the Libyan context, several studies (Alshbili \& Elamer, 2019) suggested that the level of SER is low when compared with Western countries (Loh et al., 2015). However, when Ahmad (2004) examined managers perceptions of Libyan industrial companies regarding the most important reasons that discourage Libyan companies from disclosing information, their findings show that the lack of experience, lack of qualification and training, lack of requirements and guidelines by central agencies and lack of standards published by accounting professional bodies were identified as the most important barriers, and the cost of data collection and publication, and avoiding any intervention by central agencies were identified as the least significant barriers. Although these findings might be relevant and important to policymakers, the study, however, has been unsuccessful in examining the actual barriers that impede them from engaging in disclosing information regarding the environment.

All in all, there is no single barrier, per se, for not disclosing SER information, instead, institutions, regulations and culture, which vary in many countries, are significant in the monitoring firms' actions and the effective enforcement of SER related rules (Dhaliwal et al., 2014). This review also shows that most of the earlier research studies on barriers to SER have carried out empirical investigations on the importance of barriers of SER using questionnaires (Ahmad, 2004; De Villiers, 2003), and outside the oil gas sector using interview methods (Ahmad \& Ishwerf, 2014; Beddewela \& Herzig, 2013; Belal \& Cooper, 2011). In contrast, this study focuses on identifying and discussing barriers arising from the institutional environment within the oil and gas industry. In doing so, our aim is to the emerging empirical research body of SER studies which adopts a developing country perspective (Ahmad \& Ishwerf, 2014; Belal \& Cooper, 2011; Hossain et al., 2016; Martin \& Hadley, 2008) in a weak institutional setting, with a specific focus on the presence and implications of institutional voids for SER in the Libyan context.

\section{2 | Institutional voids and SER}

In the management literature, the theory around institutional voids-a component of institutional theory-is not new (Khanna \& Palepu, 2010), and it usually represents a case where "institutional arrangements that support markets are absent, weak, or fail to accomplish the role expected of them" (Mair \& Marti, 2009, p. 422). Puffer et al. (2010) described institutional void as weaknesses in the formal institutions such as government and law enforcement bodies. Likewise, Amaeshi, Adegbite, Ogbechie, et al. (2016); Amaeshi, Adegbite, and Rajwani (2016) and Mair and Marti (2009) argue that institutional vacuums usually occur as a result of the absence of institutions or when the existing institutional arrangement remains poorly structured and highly fragmented. Whilst in weak institutional contexts-such as the emerging economies-institutional voids are prevalent, companies attempt to build legitimacy and morality by signalling positive externalities and showcasing their environmental, social and sustainability activities to different stakeholder groups (Amaeshi, Adegbite, Ogbechie, et al., 2016; Amaeshi, Adegbite, \& Rajwani, 2016). Institutional voids in developing markets may consist of vacuums in the political and social arrangement (Chittoor et al., 2015), labour and product markets (Bu \& Wagner, 2016).

Within institutional theory literature, a key type of institutional void is ambiguity. Ambiguity refers to the absence of a strongly enforced institutional arrangement that leads to a void in which an abundance of different informal institutions co-exists (Luo \& Chung, 2012). In the area of SER, the existing literature suggests that any adoption of an institutional practise requires certain conditions and institutional arrangements to function, such as strong government and strong civil society organisation to make business practises accountable (Amaeshi, Adegbite, Ogbechie, et al., 2016). In this regard, strong institutional contexts can put pressures on companies to engage in SER initiatives (e.g., Kolk \& Lenfant, 2015). However, it has been argued (Amaeshi, Adegbite, \& Rajwani, 2016) that engaging in SER and its disclosure is unlikely to occur if these conditions and arrangements are absent or weak. In other words, if these conditions are not absent, it will result in institutional weaknesses and voids (Khanna \& Palepu, 2010).

Indeed, Belal and Cooper (2011) find that the absence of legal requirements and performing poorly in terms of SER reporting are key indicators for the absence of SER in Bangladesh. From an institutional void perspective, such barriers can be regarded as keys that represent the context of institutional voids in Bangladesh. Likewise, Hossain et al. (2016) find that corruption and politics, unsatisfactory implementation of laws, and a lack of government initiatives were perceived as major barriers to SER in Bangladesh. Furthermore, within the Libyan context, Ahmad and Ishwerf (2014) find that the absence of legal requirements, issues of management and fear of bad reputation, government agencies not playing a strict role and the absence of environmental civil society organisations are key barriers for nondisclosure of environmental information in the Cement industry in Libya. Thus, many SER studies in the oil and gas sector, which examine the real influence of SER initiatives remain inconclusive. For instance, Frynas (2010) and Hossain et al. (2016) suggest that SER initiatives have mostly failed in improving reporting transparency or poverty reduction. However, Frynas (2009) found that SER initiatives have a positive impact on environmental protection and oil spill prevention. Cash (2012) and Pegg (2012) suggest that failures in SER 
initiatives by oil and gas firms in Chad and China, respectively, resulting from a weak domestic state and cultural barriers. $\mathrm{Li}$ et al. (2018) suggest that the levels of institutional voids in developing countries is positively related to increasing multinational firms' opportunistic behaviour by ignoring or even neglecting the proenvironmental protection institutions that would be implemented in their home countries. In our effort to investigate these worries further, we observe that the current research on SER and principally the nascent research on SER in developing countries cannot disregard the viewpoint that most developing countries are tarnished by institutional voids, such as lack of active capital markets, weak institutions, legal environments and civil organisations, which may weaken SER in these countries. Whilst institutional voids impede effective market functioning overall, several ways for bridging institutional voids have been documented. de Lange (2016) and Mair and Marti (2009) show that whilst countries with institutional voids lack appropriate institutions to reinforce markets, they may overflow in other categories of institutional arrangements. For instance, informal institutions may substitute for formal systems (de Lange, 2016; Puffer et al., 2010). This later research explains how a firm may develop or influence an organisational field to become helpful, so as to substitute for institutional voids, through some legitimation policies, which may also be considered as developing an alternative institutional ecosystem (de Lange, 2016; Puffer et al., 2010). Table 2 represents a summary of studies conducted on the barriers for SER.

\section{3 | RESEARCH DESIGN AND METHOD}

This section discusses how this study was designed, comprising the selection of the relevant managers of oil and gas firms and the use of in-depth interviews to obtain data about the actual barriers that act as major impediments to SER development in the Libyan oil and gas industry.

\subsection{Selection of the interviewees}

This research adopted a semi-structured interview design (Saunders et al., 2016) to examine the perceptions of managers with respect to the actual barriers that act as major impediments to SER development in the Libyan oil and gas industry. We used semi-structured interviews because it enabled the researchers to rapidly review and delve deeper into given information, adjust questions as required, appropriateness for gathering views of the respondent about the reasons for low of specific practise, thus, helps to gain more clarification (Pathak \& Intratat, 2012). The first group, that is, managers, were chosen because of their close proximity to react to the demands/pressures to disclose SER information. From this identification, the relevant managers, such as finance managers, director of finance, head of accounts and budget, accounts managers, head of health, safety and environment, were targeted. The interviews, which range between 43 and $78 \mathrm{~min}$, were to get a top-line view of how these managers
TABLE 2 Summary of studies conducted on the barriers of SER

\begin{tabular}{|c|c|}
\hline Author and country & The barriers of SER \\
\hline $\begin{array}{l}\text { De Villiers (2003), South } \\
\text { Africa }\end{array}$ & $\begin{array}{l}\text { Absence of legal requirements, no } \\
\text { demand for CSR information, CSR is } \\
\text { not applicable to particular industry, } \\
\text { no motivation to disclose CSR } \\
\text { information, and the costs of } \\
\text { disclosure exceed benefits of it. }\end{array}$ \\
\hline Ahmad (2004), Libya & $\begin{array}{l}\text { The lack of experience, lack of } \\
\text { qualification and training, lack of } \\
\text { requirements and guidelines by } \\
\text { central agencies, and lack of } \\
\text { standards published by accounting } \\
\text { professional bodies. }\end{array}$ \\
\hline $\begin{array}{l}\text { Thompson and } \\
\text { Zakaria (2004), Malaysia }\end{array}$ & $\begin{array}{l}\text { Lack of government and public } \\
\text { pressures as well as lack of perceived } \\
\text { benefits from such practises. }\end{array}$ \\
\hline Gao et al. (2005), China & $\begin{array}{l}\text { Little external pressures that } \mathrm{HK} \\
\text { companies have traditionally faced. }\end{array}$ \\
\hline $\begin{array}{l}\text { Belal and Lubinin (2009), } \\
\text { Russia }\end{array}$ & $\begin{array}{l}\text { Lack of mandatory requirements for } \\
\text { CSR reporting and lack of strong } \\
\text { non-government organisations and } \\
\text { other pressure groups }\end{array}$ \\
\hline $\begin{array}{l}\text { Belal and Cooper (2011), } \\
\text { Bangladesh }\end{array}$ & $\begin{array}{l}\text { Absence of resources, absence of legal } \\
\text { requirements, the profit imperative, } \\
\text { absence of awareness and } \\
\text { knowledge, performing poorly in } \\
\text { terms of CSR reporting and the fear } \\
\text { of bad publicity }\end{array}$ \\
\hline $\begin{array}{l}\text { Beddewela and } \\
\text { Herzig (2013), Sri Lanka }\end{array}$ & $\begin{array}{l}\text { Absence of complying with formal } \\
\text { institutionalised processes for } \\
\text { reporting CSR information. }\end{array}$ \\
\hline $\begin{array}{l}\text { Ahmad and } \\
\text { Ishwerf (2014), Cement } \\
\text { industry in Libya }\end{array}$ & $\begin{array}{l}\text { Absence of legal requirements, issues } \\
\text { management and fear of bad } \\
\text { reputation, no existing competition, } \\
\text { government agencies does not play a } \\
\text { strict role, and absence of } \\
\text { environmental civil society } \\
\text { organisations. }\end{array}$ \\
\hline $\begin{array}{l}\text { Hossain et al. (2016) } \\
\text { Bangladesh }\end{array}$ & $\begin{array}{l}\text { Lack of coordination, corruption and } \\
\text { politics, unsatisfactory } \\
\text { implementation of laws, lack of } \\
\text { government initiatives. }\end{array}$ \\
\hline
\end{tabular}

understand SER and respond to it. Consistent with our research questions, our interviews were meant to capture the barriers and motivation of SER in the Libyan oil and gas industry. The second group was regulators and policymakers within the NOC who were identified by companies' managers to be the responsible body for pressuring the companies to disclose their SER information (see Table 3).

The selection of interviewees was based upon the interviewee's agreement in willingness to be interviewed; and their knowledge on the subject to assure that all information is covered by the interviews (Bailey \& Peck, 2013). This process has offered to gather reliable information about SER in Libya and the factors that act as major impediments to SER development. The oil and gas sector has two significant features relevant to our analysis. Firstly, as we debate in the 
TAB LE 3 Profile of the Interviewees (Companies oil and gas managers)

\begin{tabular}{llllll} 
Case & Firms & Firm type & Profession of interviewee & Gender & Duration of the interview (min) \\
\hline 1 & A & L & Financial manager & M & 73 \\
\hline 2 & B & JV & Head of health, safety and environment & M & 57 \\
\hline 3 & A & L & Quality manager & M & 51 \\
\hline 4 & C & L & Accounts manager & F & 46 \\
\hline 5 & D & JV & Communication manager & M & 48 \\
\hline 6 & E & F & Head of health, safety and environment & M & 58 \\
\hline 7 & F & JV & Financial manager & M & 61 \\
\hline 8 & G & JV & Environmental manager & M & 65 \\
\hline 9 & H & JV & Head of accounts and budget & M & 53 \\
\hline 10 & I & F & Director of finance & M & 68 \\
\hline 11 & J & F & Head of health, safety and environment & M & 51 \\
\hline 12 & K & L & Environmental manager & F & 43 \\
\hline 13 & L & F & Auditor & M & 53 \\
\hline 14 & M & L & Auditor & \\
\hline
\end{tabular}

Note: $\mathrm{L}=$ Local company; JV = Joint venture company; $\mathrm{F}=$ Foreign company; $\mathrm{M}$ = Male participant; $\mathrm{F}$ = Female participant.

TAB LE 4 Profile of the Interviewees (policy and decision makers within NOC)

\begin{tabular}{llll} 
Name of the organisation & Code for the interviewee & Gender & Duration of the interview (min) \\
NOC & Interviewee one & $M$ & 78 \\
NOC & Interviewee two & $M$ & 73 \\
NOC & Interviewee three & $M$ & 64 \\
NOC & Interviewee four & M & 56 \\
NOC & Interviewee five & M & 66 \\
NOC & Interviewee six & M & 69 \\
\hline
\end{tabular}

literature review when it comes to SER issues, this sector is one of the most intensely criticised sector (Frynas, 2009). Second, the oil and gas sector is one of the most universal businesses and is controlled by a number of the world's largest firms. This makes all SER issues more multifaceted than in other industries because oil and gas companies have to manage a wide diversity of cultures, political systems, and levels of corruption, economic and social development. Lastly, this industry contains several risks such as offshore operations, land transportation, health and safety management, human rights and economic development.

\section{2 | Data collection}

We conducted semi-structured interviews with 14 corporate managers working mostly in the top and middle management levels who were involved in managing SER related practises across different companies were interviewed and six policy and decision-makers to explore the actual barriers that act as major impediments to SER development in the Libyan oil and gas industry (see Tables 3 and 4). Two out of those interviewees were women because of the political situation in Libya that affects the employment of females. Part of the data collection procedure involved 3-month fieldwork in Libya between September and December 2014.

Our methodology helped to understand, contextualise and strictly validate the obstacles as well as the experiences of SER in Libya and thus formed the basis of the subsequent descriptions and discussions. There was a very high degree of agreement amongst interviewees' comments. The data collected were mostly representative because of the inclusion of both internal and external sources (mangers and policymakers).

\section{3 | Data analysis}

After the data collection process was completed, the analysis of the semi-structured interview data was conducted in four stages as Miles and Huberman (1994) has endorsed. The first stage was to transcribe every interview in Arabic into a Word document. The second stage was to carry out a microanalysis of every interview, to understand any unseen meanings within the paragraphs, sentences and words. A translation of every interview from Arabic into English was then 
completed as the third stage and great effort was made to retain the original meanings in every instance. The final stage was to transfer and sort all interviews as a project in NVivo 10 software-a qualitative data analysis software-and the inter-coder reliability was over $85 \%$. Secondary analysis has begun for all interviews by developing a system of codes to categorise the data through the thematic analysis technique (King \& Horrocks, 2010).

The thematic analysis coding involved reading and re-reading the interview transcript and looking for patterns of themes across the full dataset based on the research question and pre-defined variables. We analysed the interview data using thematic analysis, which is a process of identifying, analysing, and conveying repeated patterns of meaning in a dataset (Braun \& Clarke, 2006). A theme is a category identified by the researcher that relates to the research questions, builds on codes identified in the transcript or document and provides the researcher with a basis to have a theoretical understanding of the data (Braun \& Clarke, 2006, p. 580). This process was carried out through three stages, as suggested by King and Horrocks (2010); the descriptive/initial coding stage, the interpretive coding stage and defining overarching themes stage. Those processes enabled us to identify and extract the themes that were recurrent in the interviewees' accounts. The analysis was then strengthened by a further manual review of the codes, which at many points enable us to construct additional codes. The rationale behind the combination is to enhance research effectiveness and to emphasis, the central role of the researcher in the analysis process, as coding and analysis "is not a merely technical task" and that "no mechanism can replace the mind and creativity of the researcher" (Marshall \& Rossman, 2010, pp. 218-219). From this first level of coding, we identified five key themes to emerge from the data about the rationale behind the institutional voids in Libya. They are as follows: (i) The absence of EGA's role, (ii) The absence of clear legal requirements referring to SER, (iii) Shortage of knowledge and awareness, (iv) Lack of motivation from government and fear of change, (v) Absence of civil society organisations.

Taking into account Libya's institutional context on the one hand and based on previous research, on the other hand, the subsequent findings examine five institutional voids in Libya as generated by the research data. Interviews were normally unanimous. Discussions take a less normative approach towards these voids, which is prevalent in the extant literature, but consider the peculiarity and specificity of the Libyan context.

\section{4 | FINDINGS}

In understanding the rationales behind the factors that act as major impediments to SER development in the oil and gas firms functioning in Libya, the findings of the analysed data show that the absence of EGA's role, the absence of clear legal requirements referring to SER, shortage of knowledge and awareness, lack of motivation from and government and fear of change, absence of civil society organisations, were perceived as the major barriers that hinder SER development in Libya. The following section offers a summary of the responses made by the oil and gas managers on the actual barriers that act as major impediments to SER development in the Libyan oil and gas industry.

\section{1 | The absence of the environment general authority's role}

Although the Libyan government has established a technical centre for the protection of the environment under the Law No (263) of 2000, currently known as the EGA (ENPI-SEIS Country Report, 2015), the analysed data revealed that this institutional authority faces a chronic problem of being unable to tackle issues of sustainability, comprising SER practise, due to the non-application of laws. Although the government brought in Law No (15) of 2003, to reduce the negative influences of the firms' activities on the environment, protect it, achieving sustainability development (Atia et al., 2020); and integrated planning of the community and encourage them for disclosure, this institutional authority seems to be weak in terms of playing its role. Indeed, according to the ENPI-SEIS Country Report (2015, p. 11), the reasons behind the weakness in enforcing the environmental law by the EGA is attributable to problems such as "a lack of equipment, trained personnel and general awareness that are inhibiting the consistent implementation and enforcement of environmental laws in Libya". Accordingly, although Libya is one of the first Arab countries to establish environmental laws with very important legislation and regulations, such legislation and regulations were not activated by the previous regime, or after the recent changes. Unsurprisingly, this authority was identified by the companies' managers (e.g., Communication Manager of joint venture firm two, 2014; Senior Manager of Human Resources, NOC, 2014 amongst others) as an important institutional factor that should play a role in such practises. However, commenting on whether oil and gas managers are pressurised to engage in SER and its disclosure, one manager from JV Company remarks:

Look, the National Oil Corporation and our company work in the same way, and we use their guidelines in terms of reporting our information. However, in terms of disclosure and whether we are pressurised, I would say no. The EGA is the only body who is expected to play a role in this process, but its role is absolutely non-existent.(Communication Manager, JV Company Two, 2014)

Even law No (15) issued by the General Authority of Environment for environment protection and improvement, does not officially require disclosure of such information.(Financial Manager, JV Company One, 2014)

In fact, the Law No (15) of 2003, issued by the EGA, can be regarded as Libya's most significant law on environmental protection, describing and outlining visibly and clearly environmental terms (ENPI-SEIS 
Country Report, 2015). The overall objective of this law is that all companies and organisations have to make all efforts to pay attention to issues such as control of pollution, and must consider the ways and the means essential to sustain an environmentally friendly balance when planning for further improvement (article 2, Law No. 15 of 2003 for protecting improvement of the environment). The general goal of this is to align the business objectives with advanced economic, environmental, social and sustainable development in Libya. One such way to do so is by enforcing the existing law and updating it in relation to the concept of disclosure, as noted below by interviewee six within the NOC:

The general authority of environment has Law No (15) that obliges companies to protect and improve the environment. This law encourages companies to contribute towards sustainable development projects that partly fulfil the needs of the present and future generations. Local companies have their own social responsibility policy and have health, safety and environment policies. [But] these companies are asked to provide the National Oil Corporation and Environment General Authority with the required information on a yearly basis by using pre-designed forms [...].(Interviewee Six, NOC, 2014)

Whilst the findings of the interview support the claims that EGA should play a role in SER, it is clear from the above findings that there is an institutional void, identified by the analysed data, and that the EGA is not an effective actor. Although the EGA has been created in order to tackle issues of sustainability comprising SER practise, this authority faces a "chronic problem" of being unable to tackle issues including SER practise, due to their absent role resulting from problems such as the lack of equipment, trained personnel and general awareness (ENPI-SEIS Country Report, 2015). Indeed, law enforcement tends to be limited because of the administrative systems and their inactivity because of the context of the current political instability and lack of security in the country. Therefore, in the light of the absence of law enforcement, and its fragile state environment, it is uncertain as to how much official regulations would be useful in this respect (Elamer et al., 2018; Elamer, Ntim, \& Abdou, 2020; Elamer, Ntim, Abdou, Owusu, et al., 2020; Elamer, Ntim, Abdou, \& Pyke, 2019; Elamer, Ntim, Abdou, Zalata, \& Elmagrhi, 2019). Yet, we should consider whether the Libyan EGA could become more adequately structured, and powerful enough to propel firms towards environmental, social and sustainability disclosure leading to an increased level of SER practise.

\section{2 | The absence of clear legal requirements referring to SER}

Although Libya's political regimes have recently been changing, similar to other developing countries worldwide, the analysed data show that the disclosure of environmental and social information in Libya is still not mandatory as yet and formal regulations do not require companies to disclose such information. The postwar government, however, has created its own SER guidelines (i.e., HSE.GDL.001.00 and HSE. PRO.002.00 social responsibility monitoring reporting guidelines) that embedded its unique economic situation and business culture to encourage firms to be more transparent in accounting practises, but it is not mandatory just yet. In contrast, firms in developed countries such as the USA, Canada, Japan, Germany and France practise and disclose SER information through their annual reports, separate ESS reports and websites, as a result of the strict laws and regulations towards SER issues. For instance, the Directive 2014/95/EU of the European Parliament and the Council was issued in 2014, which relates to the disclosure of non-financial and diversity information by certain large undertakings and groups such as the way they operate and manage social and environmental challenges. However, in the case of Libya, as the analysed data revealed, such laws to embrace SER practise are lacking. In such an instance, one manager from JV company two and director of finance, foreign company two explain that the rationale that hinders SER development within this industry is the absence of a law that refers to SER, by remarking:

[...], the absence of law. Disclosure of environmental, social and sustainability information in Libya is not mandatory, and most firms will say, 'We will just comply if we are lawfully obligated.' That's why I believe environmental, social and sustainability disclosure here [Libya] is low(Communication Manager, JV Company Two, 2014)

[...] lack of legislation by the state. Many government authorities have the idea that disclosure of environmental, social and sustainability information is only a moral obligation. It is not required by laws in a clear and concise manner(Director of Finance, Foreign Company Two, 2014)

Likewise, one external actor from the NOC affirms such law's absence by claiming:

Most companies do not disclose much of their social and environmental information because the law does not require it.(Interviewee Five, NOC, 2014)

The above analysis of the gathered data, therefore, shows that the lack of mandatory requirements to disclose social and environmental information provides oil and gas companies with enough justification for not disclosing greatly on these issues, especially in the postQadhafi state where the local and non-state actors drive the transition. Whilst the environmental, social and sustainability disclosure is always made in response to the claim from state agencies as a result of issuing official rules; in case of Libya where law enforcement is absent and Libya's fragile state environment, it is uncertain as to what 
degree official regulations would be useful in this respect. Empirically, this finding is in line with the results of past studies (Ahmad \& Ishwerf, 2014; Belal \& Cooper, 2011; De Villiers, 2003; Hossain et al., 2016) that suggest the absence of legal requirements is a key barrier for low and/or non-disclosure of SER information in developing countries contexts.

\section{3 $\quad$ Shortage of knowledge and awareness}

Because the concept of SER is fairly new for firms that operate in Libya, the analysed data show that some firms are not accustomed to its procedures and necessities. The analysed data revealed that the Libyan business' knowledge and awareness of SER practise are low, causing the influence of SER on purchasing behaviour to be of only a theoretical nature and, not of practical relevance. Oil and gas managers' personal principles and their awareness towards SER are significant, and if they are aware of the pollution that their firms make on society and environment, possibly that will aid them to appreciate the significance of SER practise. Whilst SER is still an emerging subject and whilst it is still developing in some respects, some managers blamed local managers of oil and gas companies who view such corporate information as confidential information which should be kept internalised. This perception suggests that oil and gas senior managers have not yet appreciated the benefits of SER practise. For example, the environmental manager of the local company four remarks:

[...] We do not have much knowledge about what information should be included and what should not; if we disclose something that is not really beneficial and might be harmful, then this might generate bad and adverse publicity(Environmental Manager, Local Company Four, 2014)

Another manager from the JV company five adds:

Within the Libyan environment, many local companies' managers lack the knowledge and understanding of the importance of environmental, social and sustainability information. They think it is something really sensitive and confidential and it should be kept within the firm(Head of Accounts and Budget, JV Company Five, 2014)

An external actor from the NOC shared a similar view and added:

Most local companies have the idea that this environmental, social and sustainability information is private and confidential and should not be disclosed, due the lack of the value of social and environmental activities from the public(Interviewee five, NOC, 2014)
Whilst there seems to be a considerable level of agreement about the lack of knowledge on the benefits of SER practise that acts as a major impediment for its development within firms functioning in the Libyan oil and gas industry. Likewise, the data analysed also show that some managers of those firms shed light on the qualifications issue by pointing out that some managers appear to be not qualified enough and are usually appointed by the government. Practically, all decisions including SER come from the board or management, but such managers (according to the interview data) usually lack training and do not have enough understanding about the significance and the benefits of environmental, social and sustainability disclosure in decision-making process; this influence negatively on SER practise. This perhaps is attributed to the fact that accounting education in Libya still depends on old curricula and does not teach social responsibility modules (Alshbili \& Elamer, 2020). This perception is highly acknowledged particularly amongst the local managers of oil and gas managers suggesting that there is a need for the accounting education system in Libya to integrate social and environmental awareness and/or some training on SER. Commenting on this issue, one auditor from local company one remarks:

[...] I think it is probably attributed to the lack of awareness and knowledge about what SER is and the benefits that can be derived from a good SER practice. I mean within the Libyan context; managers are normally appointed by the state. Usually, those managers have relevant experience in oil fields, but do not have an awareness of social responsibility, nor full understanding and recognition of the importance of disclosing social and environmental information.(Auditor, Local Company One, 2014)

The other concern surrounding the very low awareness of SER is the absence of demand for disclosures. A number of interviewees stressed this absence of demand for voluntary disclosures. For example, the auditor from foreign company four commented:

There is currently no demand for it from us.(Auditor,

Foreign Company Four, 2014)

\subsection{Lack of motivation from the government and fear of change}

Some governments in developed countries motivate companies to engage and disclose their SER information through, for example, providing tax benefits/exemptions (McLaughlin et al., 2019) or giving them loans. Despite that fact some organisations in Libya (e.g., the national oil corporation and the EGA), are expected to come forward and encourage the corporate sector to improve their SER activities by providing, for example, tax incentives, arrange awards such as SER awards for organisations, which could encourage firms to disclose more SER information, this is not the case within the Libyan context, 
as explained by the respondents. This perhaps attributed to the context of the political instability in the country. The lack of motivation from government acts has been identified as a major impediment to SER development; therefore, it contributes and provides enough justification for the oil and gas companies not to disclose their SER information intensively. They thought that this could be amongst the reasons why SER is not well developed:

There is no motivation from the government. They do not ask for it; they do not demand it. Even if we get involved in environmental, social and sustainability activities on a voluntary basis, we will not get reward for it. Why should we get involved? In developed countries, they get tax exemptions. Here, there is no tax benefit.(Auditor, Local Company One, 2014)

[...] no motivation from government to push companies to participate in disclosure. To become socially responsible, firms need some motivations and incentives. Companies need to know if their environmental, social and sustainability contributions in the society are recognised by the government. They need to see whether there is penalty for not doing it, or there is a reward for it. If we do not feel we got recognized, we will not disclose too much of our environmental, social and sustainability activities [...](Financial Manager, JV Company Three, 2014)

Similarly, some firms within Libya also fear of change, as the change is not always successful. Organisational culture plays an important role in SER and its disclosure developments, and therefore change is always risky, and care must be taken when firms make changes for better success and to attain the proposed target or objective. Libya has witnessed massive changes over the last few years; however, such changes still have not played the role that they were expected to play. The director of finance of a foreign company two explains:

From my point of view, this is because of firms' policies. Some firms constantly seek alteration and they are prepared to face the consequences, whilst there are firms that fancy the constancy and they feel afraid from the failure which might result from the alteration. Regrettably, local companies are the firms have doubts about alteration(Director of Finance, Foreign Company Two, 2014)

\section{5 | The absence of civil society organisations}

Finally, the availability of civil society organisations can put pressure on firms to reveal their environmental and social information (Hassan et al., 2020; Khatib et al., 2020; Roberts et al., 2020, b) such as the
Friends of the Earth in the UK. Whilst civil society networks have emerged in Libya after the Arab Spring in general, and the recent changes in Libya in particular, their influence on and involvement with media to reach the general public and key decision-makers to impact on policymaking and planning is still lacking (Foundation for the future, 2012). The degree of such absence of pressure was clearly identified and explained by several interviewees:

The civil society organisations are not active; they do not play any role. Their role is absolutely non-existent. The country is changing, but they are still sleeping. That is why oil and gas companies do not engage too much in SER activities or their disclosure(Environmental Manager, JV Company Four, 2014)

[...] absence of civil society' organisations. There were no civil society' organisations before 2011 in the country. Now, they have been created. You know, the more pressure from the civil society organisations on companies, the more social programmes and sustainable development projects to engage in, then the more disclosure would arise.(Director of Finance, Foreign Company Two, 2014)

To sum up, the above findings above give some significant, emergent themes concerning the barriers that act as major impediments to SER development. It is evident that most of the respondents have highlighted different reasons that contribute to the impediments to SER development in such companies. These reasons include the absence of the EGA's role, absence of clear legal requirements referring to SER, shortage of knowledge and awareness, lack of motivation from government and fear of change, and absence of a civil society's organisations. The low level of environmental and social disclosure can be explained; therefore, in relation to the debate that such practise is always done in response to the call from state agencies through official rules and regulations. Also, this result suggests that a lack of civil rights and free media (Tilt, 2018), may lead to weak civil society organisational mechanisms for encouraging SER.

\section{5 | CONCLUSIONS, CONTRIBUTIONS AND FURTHER RESEARCH}

This research aimed to examine the perceptions of managers in Libya regarding the actual barriers that act as major impediments to SER towards sustainable development in the Libyan oil and gas industry. The analysis of the data reveals that the absence of EGA's role, absence of clear legal requirements that refer to SER, the shortage of knowledge and awareness, lack of motivation from government and fear of change, and absence of civil society organisations create obstacles for companies to engage intensively in SER practises in Libya. Our research suggests that these voids act as barriers for firms 
to intensively involve in SER in Libya and achieve greater accountability in the local context.

The evidence of our research develops our understanding of institutional voids, in this case of SER in a developing country context. Although firms do engage in SER (although still low) to obtain its licence to operate in the country, for example by disclosing some SER information, the identified institutional voids suggest that firms rarely seem to engage intensively in voluntary SER in a developing country context. As such, our findings have implications for regulators, policymakers, practitioners and companies to overcome these institutional voids to develop a more focused agenda of SER when considering regulations for disclosure. In other words, the factors that are identified and derived from the analysed data may offer a valuable indication to managers of oil and gas firms regarding how to get engaged with main institutional actors, such as the EGA in order to develop a more focused agenda of SER activity. As such, if implemented in a more sensible context, companies could ensure that rather than just short-term business advantages, more constant long-term competitive benefits are achieved. Therefore, government policies will require to be thoroughly pilot verified, studying how they may skew the context, before introducing future plans that may be well-intentioned although that could also make other problems. Specifically, identifying the process of field development and legitimation approaches, particularly considering institutional voids, can inform broader policies for stimulating corporate governance and SER initiatives.

Overall, our research adds to the knowledge by contributing to the emerging empirical research strand of SER and sustainable development studies that adopt a developing country perspective (Ahmad \& Ishwerf, 2014; Belal \& Cooper, 2011; Hossain et al., 2016; Martin \& Hadley, 2008). Additionally, by using the concept of institutional voids in the area of SER, we contribute to the institutional voids literature towards understanding how different contextual barriers (e.g., the absence of EGA's role) act as major impediments to SER towards sustainable development in a fragile state context. This is of concern not only to the government and policymakers but also to the broader public. Our study suggests that we need to understand the association between a firm's institutional context and its strategic choices re SER. Specifically, institutional voids have much potential to shed essential light on this association, by facilitating to direct our consideration to the attributes of institutions that matter more to how firms behave.

The findings of our study are, nevertheless, have several limitations. First, our research conclusion is based on a relatively small number of interviews within a specific developing country context. Future studies could aim to capture responses to SER in the context of other industries through detailed case studies to provide an overall composite assessment and a more complete understanding of barriers to SER in Libya. Second, comparative studies examining institutional voids in developed and developing countries and the resulting level of environmental, social and sustainability disclosures by companies could also extend our initial findings.

\section{ORCID}

Ibrahem Alshbili (D) https://orcid.org/0000-0002-7906-2487

Ahmed A. Elamer (D) https://orcid.org/0000-0002-9241-9081

\section{ENDNOTE}

${ }^{1}$ In Libya context institutional voids denote circumstances where significant institutional arrangements required to strengthen markets are non-existent or excessively fragile to work in the similar way as seen in developed markets. Though, institutional voids may supplementary generate a chance for substitution by other institutional arrangements or a nonconformity by outliers from the institutional normative limitation (Amaeshi et al., 2016b; Mair \& Marti, 2009; Lepoutre \& Valente, 2012).

\section{REFERENCES}

Abdou, H., Ellelly, N., Elamer, A., Hussainey, K., \& Yazdifar, H. (2020). Corporate governance and earnings management nexus: Evidence from the UK and Egypt using neural networks. International Journal of Finance and Economics, 1-48 ISSN: 1076-9307. https://doi.org/10. 1002/ijfe.2120.

Adams, C. A. (2004). The ethical, social and environmental reportingperformance portrayal gap. Accounting, Auditing \& Accountability Journal, 17(5), 731-757.

Adhikariparajul, M., Hassan, A., Fletcher, M., \& Elamer, A. A. (2019). Integrated reporting in UKhigher education institutions. Sustainability Accounting, Management and Policy Journal, 10, 844-876. https://doi. org/10.1108/SAMPJ-03-2018-0093

Ahmad, N. S. M. (2004). Corporate environmental disclosure in Libya: Evidence and environmental determinism theory (PhD). Napier University, Edinburgh, Scotland.

Ahmad, N. S. M., \& Ishwerf, A. I. (2014). Forces and obstacles for corporate environmental disclosure (CED) in Libya: Perspective of stakeholders. Review of Integrative Business and Economics, 2(1), 65-80.

Al-Abdin, A., Roy, T., \& Nicholson, J. D. (2018). Researching corporate social responsibility in the Middle East: The current state and future directions. Corporate Social Responsibility and Environmental Management, 25(1), 47-65.

AlHares, A., Elamer, A., Alshbili, I., \& Moustafa, M. W. (2020). Board structure and corporate $R \& D$ intensity: Evidence from Forbes global 2000. International Journal of Accounting and Information Management, 28 (3), 1-25.

Ali, W., \& Frynas, J. G. (2018). The role of normative CSR-promoting institutions in stimulating CSR disclosures in developing countries. Corporate Social Responsibility and Environmental Management, 25(4), 373-390.

Ali, W., Frynas, J. G., \& Mahmood, Z. (2017). Determinants of corporate social responsibility (CSR) disclosure in developed and developing countries: A literature review. Corporate Social Responsibility and Environmental Management., 24, 273-294. https://doi.org/10.1002/csr. 1410

Alnabsha, A., Abdou, H. A., Ntim, C. G., \& Elamer, A. A. (2018). Corporate boards, ownership structures and corporate disclosures: Evidence from a developing country. Journal of Applied Accounting Research, 19 (1), 20-41.

Alshbili, I., \& Elamer, A. (2020). The vocational skills gap in accounting education curricula: Empirical evidence from the UK. International Journal of Management in Education., 14(3), 271-292.

Alshbili, l., \& Elamer, A. A. (2019). The influence of institutional context on corporate social responsibility disclosure: A case of a developing country. Journal of Sustainable Finance \& Investment, 10(3), 269-293.

Alshbili, I., Elamer, A. A., \& Beddewela, E. (2019). Ownership types, corporate governance and corporate social responsibility disclosures: Empirical evidence from a developing country. Accounting Research Journal, 33, 148-166. https://doi.org/10.1108/ARJ-03-2018-0060 
Amaeshi, K., Adegbite, E., Ogbechie, C., Idemudia, U., Kan, K. A. S., Issa, M., \& Anakwue, O. I. (2016). Corporate social responsibility in SMEs: A shift from philanthropy to institutional works? Journal of Business Ethics, 138(2), 385-400.

Amaeshi, K., Adegbite, E., \& Rajwani, T. (2016). Corporate social responsibility in challenging and non-enabling institutional contexts: Do institutional voids matter? Journal of Business Ethics, 134(1), 135-153.

Anser, M. K., Zhang, Z., \& Kanwal, L. (2018). Moderating effect of innovation on corporate social responsibility and firm performance in realm of sustainable development. Corporate Social Responsibility and Environmental Management, 25(5), 799-806.

Atia, N. G., Bassily, M. A., \& Elamer, A. (2020). Do life-cycle costing and assessment integration support decision-making towards sustainable development? Journal of Cleaner Production, 267, 1-45.

Bailey, B. C., \& Peck, S. I. (2013). Boardroom strategic decision-making style: Understanding the antecedents. Corporate Governance: An International Review, 21(2), 131-146.

Beddewela, E., \& Herzig, C. (2013). Corporate social reporting by MNC's subsidiaries in Sri Lanka. Accounting Forum, 37(2), 135-149.

Belal, A. R., \& Cooper, S. (2011). The absence of corporate social responsibility reporting in Bangladesh. Critical Perspectives on Accounting, 22(7), 654-667.

Belal, A. R., Kabir, M. R., Cooper, S., Dey, P., Khan, N. A., Rahman, T., \& Ali, M. (2010). Corporate environmental and climate change disclosures: Empirical evidence from Bangladesh. Research in Accounting in Emerging Economies, 10, 145-167.

Belal, A. R., \& Lubinin, V. (2009). Russia: Corporate social disclosures. In W. L. F. Samuel \& O. Idowu (Eds.), Global practices of corporate social responsibility (pp. 165-180). Berlin, Germany: Springer.

Boduszyński, M. P., \& Pickard, D. (2013). Libya starts from scratch. Journal of Democracy, 24(4), 86-96.

Braun, V., \& Clarke, V. (2006). Using thematic analysis in psychology. Qualitative Research in Psychology, 3(2), 77-101.

Bu, M., \& Wagner, M. (2016). Racing to the bottom and racing to the top: The crucial role of firm characteristics in foreign direct investment choices. Journal of International Business Studies, 47(9), 1032-1057.

Bufarwa, I., Ntim, C., Elamer, A., \& AlHares, A. (2020). Gender diversity, corporate governance and financial risk disclosure in the UK. International Journal of Law and Management in press. https://doi.org/10. 1108/IJLMA-10-2018-0245.

Bux, H., Zhang, Z., \& Ahmad, N. (2020). Promoting sustainability through corporate social responsibility implementation in the manufacturing industry: An empirical analysis of barriers using the ISM-MICMAC approach. Corporate Social Responsibility and Environmental Management., 27(4), 1729-1748.

Cash, A. C. (2012). Corporate social responsibility and petroleum development in sub-Saharan Africa: The case of Chad. Resources Policy, 37(2), 144-151.

Chittoor, R., Kale, P., \& Puranam, P. (2015). Business groups in developing capital markets: Towards a complementarity perspective. Strategic Management Journal, 36(9), 1277-1296.

Chivvis, C. S., \& Martini, J. (2014). Libya after Qaddafi: Lessons and implications for the future (pp. 1-97). Washington, US: Rand Corporation.

de Lange, D. E. (2016). Legitimation strategies for clean technology entrepreneurs facing institutional voids in emerging economies. Journal of International Management, 22(4), 403-415.

De Villiers, C. J. (2003). Why do south African companies not report more environmental information when managers are so positive about this kind of reporting? Meditari Accountancy Research, 11(1), 11-23.

Dhaliwal, D., Li, O. Z., Tsang, A., \& Yang, Y. G. (2014). Corporate social responsibility disclosure and the cost of equity capital: The roles of stakeholder orientation and financial transparency. Journal of Accounting and Public Policy, 33(4), 328-355.
Dobers, P., \& Halme, M. (2009). Corporate social responsibility and developing countries. Corporate Social Responsibility and Environmental Management., 16, 237-249. https://doi.org/10.1002/csr.212

Elamer, A., AlHares, A., Ntim, C. G., \& Benyazid, I. (2018). The corporate governance-risk-taking nexus: Evidence from insurance companies. International Journal of Ethics and Systems, 34(4), 493-509.

Elamer, A., Ntim, C., Abdou, H., Owusu, A., Elmagrhi, M., \& Ibrahim, A. (2020). Are bank risk disclosures informative? Evidence from debt markets. International Journal of Finance and Economics. https://doi. org/10.1002/ijfe.1849.

Elamer, A. A., Ntim, C. G., \& Abdou, H. A. (2020). Islamic governance, National Governance, and Bank risk management and disclosure in MENA countries. Business and Society, 59(5), 914-955.

Elamer, A. A., Ntim, C. G., Abdou, H. A., \& Pyke, C. (2019). Sharia supervisory boards, governance structures and operational risk disclosures: Evidence from Islamic banks in MENA countries. Global Finance Journal, 100488. https://doi.org/10.1016/j.gfj.2019.100488.

Elamer, A. A., Ntim, C. G., Abdou, H. A., Zalata, A. M., \& Elmagrhi, M. H. (2019). The impact of multi-layer governance on bank risk disclosure in emerging markets: The case of Middle East and North Africa. Accounting Forum, 43(2), 246-281.

Eljayash, K. M. (2015). Documentation of Environmental Disclosure Practices in the Oil Companies in the Countries of the Arab Spring - Some Evidences from Egypt, Libya and Tunisia. Journal of Economics, Business and Management, 3 (10), 954-960.

Elmagrhi, M. H., Ntim, C. G., Elamer, A. A., \& Zhang, Q. (2018). A study of environmental policies and regulations, governance structures, and environmental performance: The role of female directors. Business Strategy and the Environment, 28(1), 206-220.

ENPI-SEIS Country Report, L. (2015). ENPI-SEIS country report-Libya (pp. 1-16). Denmark: European Environment Agency.

Farrukh, M., Sajid, M., Lee, J. W. C., \& Shahzad, I. A. (2020). The perception of corporate social responsibility and employee engagement: Examining the underlying mechanism. Corporate Social Responsibility and Environmental Management, 27(2), 760-768.

Feng, Y., Hassan, A., \& Elamer, A. (2020). Corporate governance, ownership structure and capital structure: Evidence from Chinese real estate listed companies. International Journal of Accounting and Information Management, 28(4), 1-35.

Fontana, E. (2020). Managing diversity through transgender inclusion in developing countries: A collaborative corporate social responsibility initiative from Bangladesh. Corporate Social Responsibility and Environmental Management, 27(6), 2548-2562.

Foundation for the future, F. (2012). Mapping and participatory needs assessment of civil society in Libya. Civil Society: Reality and Challenges, 1-5. https://africanphilanthropy.issuelab.org/resource/mapping-andparticipatory-needs-assessment-of-civil-society-in-libya.html.

Frynas, J. G. (2009). Beyond corporate social responsibility. Oil Multinationals and Social Challenges, Cambridge, England: Cambridge University Press. https://doi.org/10.1017/CBO9780511581540.

Frynas, J. G. (2010). Corporate social responsibility and societal governance: Lessons from transparency in the oil and gas sector. Journal of Business Ethics, 93(2), 163-179.

Gao, S., Heravi, S., \& Xiao, J. Z. (2005). Determinants of corporate social and environmental reporting in Hong Kong: A research note. Accounting Forum, 29(2), 233-242.

García-Rodríguez, F. J., García-Rodríguez, J. L., Castilla-Gutiérrez, C., \& Major, S. A. (2013). Corporate social responsibility of oil companies in developing countries: From altruism to business strategy. Corporate Social Responsibility and Environmental Management, 20(6), 371-384.

García-Sánchez, I., Aibar-Guzmán, B., Aibar-Guzmán, C., \& Azevedo, T. (2020). CEO ability and sustainability disclosures: The mediating effect of corporate social responsibility performance. Corporate Social Responsibility and Environmental Management csr.1905, 27(4), 15651577. 
Gerged, A. M., Beddewela, E., \& Cowton, C. J. (2020). Is corporate environmental disclosure associated with firm value? A multicountry study of gulf cooperation council firms. Business Strategy and the Environment. https://doi.org/10.1002/bse.2616.

Gerged, A. M., Cowton, C. J., \& Beddewela, E. S. (2018). Towards sustainable development in the Arab Middle East and North Africa region: A longitudinal analysis of environmental disclosure in corporate annual reports. Business Strategy and the Environment, 27(4), 572-587.

Gray, R., Owen, D., \& Maunders, K. (1987). Corporate social reporting: Accounting and accountability, London, England: Prentice-Hall International.

Haque, F., \& Ntim, C. G. (2018). Environmental policy, sustainable development, governance mechanisms and environmental performance. Business Strategy and the Environment, 27(3), 415-435.

Hassan, A., Nandy, M., Roberts, L., Elamer, A. A., \& Lodh, S. (2020). The future of businesses reporting: Learning from financial and COVID-19 crises. Available at SSRN 3571571.

Hill, T. L., \& Mudambi, R. (2010). Far from Silicon Valley: How emerging economies are re-shaping our understanding of global entrepreneurship. Journal of International Management, 16(4), 321-327.

Hoque, N., Rahman, A. R. A., Molla, R. I., Noman, A. H. M., \& Bhuiyan, M. Z. H. (2018). Is corporate social responsibility pursuing pristine business goals for sustainable development? Corporate Social Responsibility and Environmental Management, 25(6), 1130-1142.

Hossain, M. M., Alam, M., Hecimovic, A., Hossain, M. A., Lema, A. C., Adams, C., \& Adams, C. (2016). Contributing barriers to corporate social and environmental responsibility practices in a developing country: A stakeholder perspective. Sustainability Accounting, Management and Policy Journal, 7(2), 319-346.

Hussein, N. A. M. A. (2012). Corporate social responsibility disclosure in response to CSR award with the moderating effect of family group affiliation in Yemen (PhD thesis). Universiti Utara Malaysia, Malaysia.

Jamali, D. (2007). The case for strategic corporate social responsibility in developing countries. Business and Society Review, 112(1), 1-27.

Javed, M., Rashid, M. A., Hussain, G., \& Ali, H. Y. (2020). The effects of corporate social responsibility on corporate reputation and firm financial performance: Moderating role of responsible leadership. Corporate Social Responsibility and Environmental Management, 27(3), 1395-1409.

Khan, M., \& Mezran, K. (2013). The Libyan economy after the revolution: Still no clear vision. Atlantic Council Issue Brief. Retrieved from www. atlanticcouncil.org.

Khanna, T., \& Palepu, K. (2010). Winning in emerging markets: A road map for strategy and execution, London, England: Harvard Business Press.

Khatib, S., Abdullah, D., Elamer, A. A., \& Abueid, R. (2020). Nudging toward diversity in the boardroom: $A$ systematic literature review of board diversity of financial institutions. Business Strategy and the Environment. https://doi.org/10.1002/bse.2665

King, N., \& Horrocks, C. (2010). Interviews in qualitative research (2nd ed.). London, UK: Sage Publications.

Kolk, A. (2005). Environmental reporting by multinationals from the triad: Convergence or divergence? Management International Review, 45(1), 145-166.

Kolk, A., \& Lenfant, F. (2015). Cross-sector collaboration, institutional gaps, and fragility: the role of social innovation partnerships in a conflictaffected region. Journal of Public Policy \& Marketing, 34(2), 287-303.

Kowalczyk, R., \& Kucharska, W. (2020). Corporate social responsibility practices incomes and outcomes: Stakeholders' pressure, culture, employee commitment, corporate reputation, and brand performance. A Polish-German cross-country study. Corporate Social Responsibility and Environmental Management., 27, 595-615.

Lagasio, V., \& Cucari, N. (2019). Corporate governance and environmental social governance disclosure: A meta-analytical review. Corporate Social Responsibility and Environmental Management., 26, 701-711. https://doi.org/10.1002/csr.1716
Lauwo, S., Kyriacou, O., \& Otusanya, O. J. (2019). When sorry is not an option: CSR reporting and 'face work' in a stigmatised industry-A case study of Barrick (acacia) gold mine in Tanzania. Critical Perspectives on Accounting, 71, 102099.

Lepoutre, Jan MWN, and Michael Valente. "Fools breaking out: The role of symbolic and material immunity in explaining institutional nonconformity." Academy of Management Journal 55.2 (2012): 285-313.

Li, J., Zhang, Y., Hu, Y., Tao, X., Jiang, W., \& Qi, L. (2018). Developed market or developing market?: A perspective of institutional theory on multinational enterprises' diversification and sustainable development with environmental protection. Business Strategy and the Environment, 27(7), 858-871.

Li, X., Gao-Zeller, X., Rizzuto, T. E., \& Yang, F. (2019). Institutional pressures on corporate social responsibility strategy in construction corporations: The role of internal motivations. Corporate Social Responsibility and Environmental Management, 26(4), 721-740.

Loh, C. M., Deegan, C., \& Inglis, R. (2015). The changing trends of corporate social and environmental disclosure within the Australian gambling industry. Accounting \& Finance, 55(3), 783-823.

Luo, X. R., \& Chung, C.-N. (2012). Filling or abusing the institutional void? Ownership and management control of public family businesses in an emerging market. Organization Science, 24(2), 591-613.

Luo, Y., \& Tung, R. L. 2007. International expansion of emerging market enterprises: A springboard perspective. Journal of International Business Studies, 38(4): 481-498.

Mair, J., \& Marti, I. (2009). Entrepreneurship in and around institutional voids: A case study from Bangladesh. Journal of Business Venturing, 24 (5), 419-435.

Marano, V., Tashman, P., \& Kostova, T. (2017). Escaping the iron cage: Liabilities of origin and CSR reporting of emerging market multinational enterprises. Journal of International Business Studies, 48(3), 386-408.

Marshall, C., \& Rossman, G. B. (2010). Qualitative research design. Thousand Oaks, CA: Sage.

Martin, A., \& Hadley, D. (2008). Corporate environmental non-reportingA UKFTSE 350 perspective. Business Strategy and the Environment, 17 (4), 245-259.

Martínez-Ferrero, J., Suárez-Fernández, O., \& García-Sánchez, I.-M. (2019). Obfuscation versus enhancement as corporate social responsibility disclosure strategies. Corporate Social Responsibility and Environmental Management, 26(2), 468-480.

McLaughlin, C., Elamer, A. A., Glen, T., AlHares, A., \& Gaber, H. R. (2019). Accounting society's acceptability of carbon taxes: Expectations and reality. Energy Policy, 131, 302-311.

Miles, M. B., \& Huberman, A. M. (1994). Qualitative data analysis: An expanded sourcebook. Thousand Oaks, CA/London: Sage.

Miniaoui, Z., Chibani, F., \& Hussainey, K. (2019). The impact of countrylevel institutional differences on corporate social responsibility disclosure engagement. Corporate Social Responsibility and Environmental Management, 26(6), 1307-1320.

Pathak, A., \& Intratat, C. (2012). Use of semi-structured interviews to investigate teacher perceptions of student collaboration. Malaysian Journal of ELT Research, 8(1), 1-10.

Pegg, S. (2012). Social responsibility and resource extraction: Are Chinese oil companies different? Resources Policy, 37(2), 160-167.

Poddar, A., Narula, S. A., \& Zutshi, A. (2019). A study of corporate social responsibility practices of the top Bombay stock exchange 500 companies in India and their alignment with the sustainable development goals. Corporate Social Responsibility and Environmental Management, 26(6), 1184-1205.

Pucheta-Martínez, M. C., \& Gallego-Álvarez, I. (2019). An international approach of the relationship between board attributes and the disclosure of corporate social responsibility issues. Corporate Social Responsibility and Environmental Management, 26(3), 612-627.

Puffer, S. M., McCarthy, D. J., \& Boisot, M. (2010). Entrepreneurship in Russia and China: The impact of formal institutional voids. Entrepreneurship Theory and Practice, 34(3), 441-467. 
Pureza, A. P., \& Lee, K. (2020). Corporate social responsibility leadership for sustainable development: An institutional logics perspective in Brazil. Corporate Social Responsibility and Environmental Management, 27 (3), 1410-1424.

Roberts, L., Hassan, A., Elamer, A., \& Nandy, M. (2020). Biodiversity and extinction accounting for sustainable development: A systematic literature review and future research directions. Business Strategy and the Environment. https://doi.org/10.1002/bse.2649

Roberts, L., Hassan, A., Nandy, M., \& Elamer, A. (2020). Nursing both the Covid 19 and biodiversity crisis together. The Alliance for Sustainability Leadership in Education. Retrieved from https://www.eauc.org.uk/ nursing_both_the_covid_19_and_biodiversity_cris.

Saunders, M., Lewis, P., \& Thornhill, A. (2016). Research methods for business students (7th ed.). Essex, England: Pearson Education Limited.

Sharma, E. (2019). A review of corporate social responsibility in developed and developing nations. Corporate Social Responsibility and Environmental Management, 26(4), 712-720.

Taylor, J., Vithayathil, J., \& Yim, D. (2018). Are corporate social responsibility (CSR) initiatives such as sustainable development and environmental policies value enhancing or window dressing? Corporate Social Responsibility and Environmental Management, 25(5), 971-980.

Thompson, P., \& Zakaria, Z. (2004). Corporate social responsibility reporting in Malaysia. Journal of Corporate Citizenship, 2004(13), 125-136.

Tiba, S., van Rijnsoever, F. J., \& Hekkert, M. P. (2019, March 1). Firms with benefits: A systematic review of responsible entrepreneurship and corporate social responsibility literature. Corporate social responsibility and environmental management, 26(2), 265-284.

Tilt, C. A. (2018). Making social and environmental accounting research relevant in developing countries: A matter of context? Social and Environmental Accountability Journal, 38(2), 145-150.
Wahba, H. (2008). Exploring the moderating effect of financial performance on the relationship between corporate environmental responsibility and institutional investors: Some Egyptian evidence. Corporate Social Responsibility and Environmental Management, 15(6), 361-371.

Waheed, A., \& Yang, J. (2019). Effect of corporate social responsibility disclosure on firms' sales performance: A perspective of stakeholder engagement and theory. Corporate Social Responsibility and Environmental Management, 26(3), 559-566.

Wu, J. (2014). The antecedents of corporate social and environmental irresponsibility. Corporate Social Responsibility and Environmental Management, 21(5), 286-300.

Zaid, M. A. A., Abuhijleh, S. T. F., \& Pucheta-Martínez, M. C. (2020). Ownership structure, stakeholder engagement, and corporate social responsibility policies: The moderating effect of board independence. Corporate Social Responsibility and Environmental Management, 27(3), 1344-1360.

Zou, H., Xie, X., Meng, X., \& Yang, M. (2019). The diffusion of corporate social responsibility through social network ties: From the perspective of strategic imitation. Corporate Social Responsibility and Environmental Management, 26(1), 186-198.

How to cite this article: Alshbili I, Elamer AA, Moustafa MW. Social and environmental reporting, sustainable development and institutional voids: Evidence from a developing country. Corp Soc Responsib Environ Manag. 2021;28:881-895. https:// doi.org/10.1002/csr.2096 